\title{
Is the Patent System the Way Forward with the CRISPR-Cas 9 Technology?
}

\author{
Franc Mali \\ University of Ljubljana, Faculty of Social Sciences, Slovenia / franc.mali@fdv.uni-lj.si
}

\begin{abstract}
CRISPR-Cas9 technology is reshaping the way scientists conduct research in genetic engineering. It is predicted to revolutionise not only the fields of medicine, biology, agriculture and industry but, much like all revolutionary technologies of the past, the way humans live. Given the anticipated and already seen benefits of CRISPR-Cas 9 in different areas of human life, this new technology may be defined as a true breakthrough scientific discovery. The article presents several challenges connected with various dimensions of the CRISPR-Cas 9 patent landscape. The central argument is that today the biggest challenge is finding a intermediary way that ensures a balance between providing sufficient openness for the further progress of basic research in CRISPR-Cas 9 such as 'niche' areas of the latest genetic engineering and adequate intellectual property rights to incentivise its commercialisation and application. The article contends the endeavours by academic scientific institutions to arrive at short-term benefits of the new CRISPR-Cas 9 technology do not constitute such an intermediary way, especially when the CRISPR-Cas 9 patent landscape is viewed as part of a series of controversial bioethical discussions that have been underway for over 40 years.
\end{abstract}

Keywords: CRISPR-Cas9, intellectual property rights, patent litigation, biopatents, open innovation models

\section{Introduction}

CRISPR-Cas9 technology is a genome-editing approach that is changing the field of genetic engineering. This genome-editing tool is reshaping the way scientists conduct research, and is predicted to revolutionise not only the fields of medicine, biology, agriculture and industry but, much like all revolutionary technologies of the past, the way humans live. The CRISPR-Cas9 technology has reinvigorated research that lay dormant for years, importantly on stem cells, while stimulating drug discovery and novel biomedical therapies. Since CRISPR-Cas9 was discovered in 2012, applications based on it are found in the areas of diagnostics, creating complex animal disease models, drug resistance, DNA storage, etc. It is a powerful innovation anticipated to bring an unparalleled impact on the future of biomedicine. This new genome-editing technique will alter our understanding of disease mechanisms and provide a powerful tool for precisely and efficiently targeting diseases. It will revolutionise the treatment of genetically-transmitted human disease, correcting defective genes within diseased bodies, and potentially banishing genetic errors 
from the germ line (EASAC Policy Report, 2017; National Academies of Sciences, Engineering, and Medicine, 2017; Egelie et al., 2016; Barrangou and Doudna, 2016).

Put simply, CRISPR-Cas9 works as a type of molecular scissors that can selectively trim away unwanted parts of the genome and replace it with new stretches of deoxyribonucleic acid (DNA). In more recent times, the popularity of this revolutionary technology has spread like wildfire. Many research labs around world dealing with genetic engineering are quickly adopting this new approach. Of course, today CRISPR-Cas 9 is not the only genome-editing technology. Researchers are still using other technologies, such as zinc finger nucleases (ZFNs) and transcription activator-like effector nucleases (TALENs). Still, CRISPR-Cas 9 is a special genome-editing approach because it is relatively simple to use compared to other approaches and also much cheaper and more efficient (Van Erp et al., 2015; Samy, 2018).

By virtue of the anticipated and already presented radical implications of CRISPR-Cas 9 for different areas of human life, this new technology may be defined as a true breakthrough in the progress of genetic engineering. The tremendous progress and applied potential of CRISPR-Cas 9 mean the financial and symbolic stakes surrounding it are enormous (Halilem et al., 2017). This largely explains why tensions concerning who holds the property rights to this revolutionary discovery are growing. In recent times, such tensions have been nowhere more evident than in the patent battle between Jennifer Doudna's research group (The University of California) and Feng Zhang' research group (The MIT/ Broad Institute). In some respects, such tensions are not new in science. Considerable tensions in science were already described by Robert Merton (1973). What is especially interesting is that today's patent battles are characterised by the extreme mutual exclusivity of the parties involved. For example, in the most disreputable case of a patent battle between the University of California and the MIT/Broad Institute one of the parties had misrepresented the whole historical narrative of the discovery of CRISPR-Cas 9. (Namely, this revolutionary discovery did not entail any eureka moment, but was the result of research activities conducted over a decade or more). This was done as part of a public relations strategy to create the public impression that only the MIT/Broad Institute deserved to be registered as the owner of the patent for CRISPR-Cas 9. For example, in his essay "Heroes of CRISPR", Eric Lander, MIT/Broad Institute Director, publicly downplayed the scientific contribution of their competitors, writing that "Jennifer Doudna would call the world's attention to the important societal issues raised by the prospect of editing the human germline" (Lander, 2016: 24). The statement suggests that Jennifer Doudna should not be seen as the creator of this important scientific innovation! The aggressiveness of the tensions indicates the role of patents in the case of CRISPR technology is not only to protect an inventor's work, but to ensure big commercial benefits accrue to institutions when inventions emerge. Robert Merton (1973) already asserted the aim of scientific tensions is not simply (symbolic) recognition and reputation, but also money and profit.

The penetration of intellectual property rights (IPR) into the genome and other realms of biology forms part of a broader trend of expanding the ownership model in the public domain, which has "a spiralling effect" (Winickoff, 2015: 15). It is not only business enterprises, but also public academic institutions that do not like wasting time on monopolising their inventions with the help of IPR. They are increasingly using various other mechanisms to realise this goal, despite the fact such approaches could cause, through strict enforcement of patents and different licensing forms, a 'bottleneck' hindering any faster progress in basic academic science.

A clear indicator of the stronger tendency of academic institutions to commercially privatise their knowledge is patent litigation. In simple terms, patent litigation describes the legal processes that unfold when someone who owns the patent for a particular invention enforces their right by suing another person for manufacturing or selling the invention without permission. The extension and intensity of patent litigation is probably slowing down the progress of basic science because both business enterprises and academic institutions worry more about patent infringement and less about how beneficial the 
improving of CRISPR-Cas 9 technology could be for the whole field of genetic engineering. We are even coming to the situation where patent litigations serve an offensive function.

Many IPR experts also believe the outcome of such patent litigations will affect control of the CRISPR platform and development of the technology. These experts contend we are in the middle of a fierce patent war, which is one reason that many promising scientific and technological fields are unnecessarily being forced to wait and see what will be the final result of this patent war. It is very important in every patent battle how the victors then assert their patent position. There is the threat that the still ongoing patent litigation concerned with CRISPR-Cas 9 will limit its use as a platform technology (Sherkow, 2017a; Sherkow, 2017b; Egelie et al., 2016). Such trends are leading us to the situation of the "tragedy of the anticommons" (Heller and Eisenberg, 1998: 698).

However, one can also find opposite IPR expert views stating that the negative impacts of patent litigation on CRISPR-Cas 9 on the further progress of human genome-editing technologies would be marginal (Feldman, 2016; Graff and Johansen, 2016; Summerfield, 2015). Such experts do not regard such instances of patent litigation as a zero-sum game. They are seen as an opportunity to arrive at new solutions, e.g. cross-licensing agreements which ensure the global proliferation of CRISPR-Cas 9 technology. In many senses, those who support the use of various IPR mechanisms when it comes to the CRISPR-Cas 9 technology are mainly continuing the long visible 'philosophy' of academic entrepreneurship. In the context of academic entrepreneurship, the patenting of inventions in the academic sector was a critical factor in the development of modern genetic engineering (Etzkowitz, 2002).

To some forms of cross-licensing agreements are trying to come in the last times also University of California and the MIT/Broad Institute, i.e. the parties involved in the controversial patent litigation at the United State Trade and Patent Office (USTPO) and European Patent Office (EPO). Both academic institutions are involved in hotly contested patent disputes, but have at the same time created spin-offs through which they have formed a more complex cross-licence agreement mechanism.

When looking back at the history of genetic engineering, the patent landscape of CRISPR-Cas 9 raises many new challenges, although similar non-exclusive licensing approaches were already encouraged at the time of the emergence of recombinant DNA technology in the late 1970s. At that time, Boyer and Cohen had discovered a method to produce recombinant DNA in bacteria. Upon filing the Cohen-Boyer patent, Stanford University created a non-exclusive licensing programme that provided a predictable legal framework for using the discovery of the two scientists. Non-exclusive licences were made available to both the business sector and academic institutions. Such a non-exclusive licensing policy of Stanford University has been embraced by the academic world as a best-practice model for the commercialisation of biotechnology (Feldman et al., 2007).

Today, in the same way the discovery of CRISPR Cas 9 provides a revolutionary technology which also brings a series of novel challenges. As we attempt to show below, the situation is being made much more complex by several dimensions of the CRISPR patenting. Namely, the inconsistent decisions made by various patent offices, the establishment of surrogate companies at universities, patent claimers' interest in agreeing on broad patents, etc. It seems the academic sector has recently shown itself to be less prepared for the complex technological challenges at some points. If it may be said that at the time of the CohenBoyer recombinant DNA technology university licensing offices at American academic institutions were taking care of the balance between control and providing access for the multiple commercial applications and ongoing scientific studies that were relying on them, then "in the time of new CRISPR-Cas 9 technology it appears that the university licensing offices have already abdicated the possibility of playing such a role" (Egelie et al., 2016: 1031).

The central thesis of our contribution is that the biggest challenge facing the academic sector is how to find an intermediate way that ensures a balance between providing sufficient openness for the further progress of CRISPR-Cas 9 as 'niche' 
areas of genetic engineering, while also giving sufficient support for intellectual property rights to retain incentives for academic innovators. The solution to this issue will impact the future progress of genetic engineering at large and may, in turn, generate proper responses to the increasing bioethical concerns. Our goal with this contribution is not to add to the stockpile of various views on institutional and policy regulation on newly emerging technologies. We instead seek to address the narrower question of how to find an intermediate way between the open and closed innovation models in the case of CRISPRCas 9 technology.

The problem with CRISPR-Cas 9 technology is not simply that the extremely wide scope of the claims made in bio-patent applications could halt the further progress of basic research. Concerns are also growing due to bioethical dilemmas arising from the patenting of CRISPR-Cas 9 technology. On one hand, we need to provide the necessary conditions for the successful development and use of CRISPR-Cas 9 across various fields of the life sciences, but also need to provide all the necessary safeguards that, in particular, no patents can be granted for CRISPR inventions, which could in any way offend human dignity and integrity. This does mean we need social rules which are flexible enough to provide the free flow of information on which the further progress of CRISPRCas 9 technology is based, but also which will take the ethical and moral implications into account.

Let us consider the use of CRISPR technology for germline interventions which could be aimed at altering a genome in a way that would affect not only the resulting child but potentially some of the child's descendants as well. Here, the question arises of whether the combination of germline intervention and patent protections could lead to forms of ownership that span an entire species (National Academies of Science, Engineering and Medicine, 2016). It will take some time for patent regulation to get up to speed with such a breakthrough technology like CRISPR-Cas 9. For that reason it is extremely important that all stakeholders involved in patent landscape dedicate attention also to ethical issues. In our article, I'll try to point out that ethical dilemmas surrounding biopatents, including CRISPR-Cas 9 patents, are not new. They appeared at the origins of modern genetic engineering. The history of genetic engineering clearly shows that diverging interpretations have always existed of how to use biopatents in practice. Of course, these interpretations have altered over time. Biogenetics has consistently progressed, for example, from small, biologicallyactive molecular compounds to complex proteins and molecules of DNA, including entire genes. It is expected that the rise of CRISPR-Cas 9 will see the ethical dimension of the patent landscape of biotechnology become ever more a subject of wider public interest.

The article has the following structure. In the following section, I highlight the negative implications of academic institutions' efforts to establish benefits of the new CRISPR-Cas 9 technology. Then, I move on to describe in more detail why the recent patent battles over the CRISPR-Cas 9 technology can be seen as part of the controversial (bioethical) discussions about biopatents that have existed for over 40 years. After that, the focus is on presenting models that advocate open access to knowledge in synthetic biology and other new technologies. Finally, some concluding words are provided.

\section{Is the CRISPR-Cas 9 patent war a sign of academic research institutions' expectations of big short-term benefits?}

Not since the early, heady days of recombinant DNA ( $\mathrm{rDNA}$ ) has a biogenetic technique so gripped the scientific imagination as CRISPR-Cas9 gene editing. Bioethicist Greely from Stanford University in California used the following analogy to stress the importance of the discovery of CRISPR-Cas 9 for modern society: CRISPR-Cas 9 can be compared with the invention of the Model T Ford in the car industry. The Model T Ford was far from the first automobile to appear in the car industry, but it was its simplicity of production, dependability and affordability that transformed the society of the time (Specter, 2015). In the same way, CRISPR-Cas9 genome editing brings unprecedented ease and precision to genetic engineering. 
It is currently difficult to forecast all the social and economic benefits flowing from the tremendous progress of CRISPR-Cas 9 genome editing. The range of potential uses of CRISPR is extremely huge. One consequence is the greater profit orientation seen in genome-editing science which »may very well signal a culture shift in academic research institutions from pure and translational research into profit-maximizing commercialization« (Sherkow, 2016: 29). The CRISPR technology is turning the ivory tower of biogenetics into a multibillion-dollar technological enterprise built on individual entrepreneurship, venture capital, start-ups, and wide-ranging university-industry collaborations (Jasanoff et al., 2015).

In this situation, the stakes for owning a patent in CRISPR technology are extremely high.

The speed at which this technology is developing has generated considerable optimism about short-term profit. The rapid growth of patent filings concerning CRISPR-Cas 9 started in 2012, essentially simultaneously with both of the leading research groups at Berkeley University and the MIT/Broad Institute that published their research breakthroughs. After that, the number of patents has continuously increased in the different aspects of the CRISPR technology landscape (it is divided into five main technology areas of high patent activity: CRISPR-Cas9 components, CRISPR-Cas activity, Vectors, Delivery, Application) (Egelie et al., 2016). Since the filing of the first patent claiming CRISPR as a gene-editing tool in 2012, the US Patent and Trademark Office (USPTO) has granted more than 1,000 patents pertaining to CRISPR in some way (Carson and Mulvaney, 2018).

Stakeholders from the university sector do not like wasting time to obtain patents to earn a profit from this revolutionary technology. This explains why some of them are entangled in prolonged and costly patent litigation. Patent litigation is a consequence of the aggressive patent 'policy' of the academic sector. In the last period, the most disreputable case of patent litigation involved two academic institutions from the United States, the University California and the MIT/Broad Institute. This case has attracted enormous public attention. It has spilled over from narrow expert and business circles to the front pages of popular media. Both parties to this 'interference proceeding' 1 at the USPTO are two groups of scientists. The first is a group led by Jennifer Doudna from the University of California who, together with Emmanuelle Charpentier from the University of Vienna, published the first results of CRISPR gene editing in prokaryotes. The second group is led by Feng Zhang from the MIT/Broad Institute who claims his team was the first to successfully implement CRISPR in eukaryotes. ${ }^{2}$ The University California group filed a patent in early 2012 to cover the basic contours of CRISPR-Cas9. Its patent claim referred to the use of a genome-editing tool in any type of cell. Six months later, the MIT/Broad Institute group filed a claim for a patent where it was demonstrated that CRISPR-Cas9 can be used on eukaryotic cells. Zhang argued that his patent claim is sufficiently different from that of the University of California and therefore both parties, that is, the University of California and the MIT/Broad Institute, should be allowed to pursue their claims independently. This interpretation by the MIT/Broad Institute was not supported by the University of California. Zhang's patent claim to use genome-editing technology in any non-cellular or cellular setting (including in human cells) was opposed by the University of California, which retaliated by filing an application with the Patent Trial and Appeal Board at the USPTO to investigate interference. After quite a long process of interference proceedings, in 2017 the Patent Trial and Appeal Board at the USPTO declared that the patents granted to the MIT/Broad Institute do not interfere with the patent claims of UC Berkeley (Sherkow, 2017c; Ku, 2017). In September 2018, the US Federal Appeals Court also ruled in favour of the Broad Institute, confirming an earlier US patent board decision that patents from the lab of the investigator Feng Zhang did not "interfere" with those sought by the University of California. This should have meant that Zhang and his team had succeeded in obtaining the patent rights (United States Court of Appeals for the Federal Circuit, 2018). Yet the story did not end there with the grant of a patent to Zhang's group. The patent fight was merely entering the next rounds, with the University California asserting that the Federal Appeals Court had wrongly sided with the MIT Institute. 
Even if we maintain the view that the bigger role for the ownership model at academic institutions will not threaten further progress in the basic science of genetic engineering, we must be aware of at least three threats likely to be strengthened by the uncompromising battles over patent rights:

1. The first threat is that the number of patent applications containing broad claims will grow in the extreme. Although certain studies concluded that scientists are optimistic about their ability to continue research despite the presence of broad patents (Nicol and Nielsen, 2003), it is generally accepted that the continuous requirement for patent breadth brings many negative implications. Patents connected with CRISPR-Cas 9 are typically drafted very broadly because this innovation falls into the category of "enabling technology", i.e. its use does not directly provide a product but enables a product to be made using other knowledge and probably technology (Sherkov and Greely, 2015; Grens, 2016; Nuffield Council for Bioethics, 2016). For example, Doudna and Charpentier's original patent application contained over 150 claims and was notably unspecific with respect to cell type (Sherkow, 2017a). Broad patents and patent thickets in fact already pose a big challenge to the whole field of genetic engineering (König et al., 2013; Van Zimmeren et al., 2011). A great challenge with patents of broad scope is that their claims may exceed what the inventor actually discovered. Broad patent claims are the key element in creating a legal monopoly over the ownership of inventions. They contain less detail than narrow claims, and therefore give the patent owner protection over a wider range of activities. Such owners seek property rights that extend beyond uses of their invention they originally anticipated or predicted, but also over any new uses that are developed (Singh, 2015; Nuffield Council for Bioethics, 2002). The big multinational pharmaceutical corporations have a strong interest in applying for extremely broadly worded patents on genetic engineering and in extending peri- ods of exclusive patent rights over their innovations (Sampat and Shadlen, 2017).

2. The second threat is that the conditions of the global CRISPR patent landscape are uncertain and non-transparent. The prolonged and costly legal entanglements at various national and transnational patent offices are the main reason that many new players (venture capitalists, IP fund managers, patent auction houses, lawyers, etc.) are arriving on the scene. Myriad interested parties are pushing and pulling in different directions. In addition, patent offices are experiencing backlogs of unexamined patent applications, which generate legal uncertainty. The situation is sometimes extremely confusing. The last interference proceedings in which UC Berkley and the MIT/Broad Institute were involved have been interpreted differently by two leading patent offices in the world. As mentioned, in February 2017 the Patent Trial and Appeal Board at the USPTO declared that the CRISPR editing of eukaryotic genomes by the MIT/Broad Institute did not interfere with the University California's patent claims. It denied the University California an exclusive patent right to the technology concerning eukaryotes. However, contrary to the USPTO, only a few months later EPO revoked the first of several patents concerning CRISPR-Cas 9 technology obtained by the MIT/Broad Institute, citing a clear lack of novelty. It granted a broad patent jointly to the University of California (Jennifer Doudna) and the University of Vienna (Emmanuelle Charpentier) (Akst, 2017). The different positions held by the US and European patent offices reveal several disparities in the outcomes of international patenting. At the global level we are far from any harmonisation of the various patent practices concerned with genes and DNA sequences. The procedures for processing patent applications still vary considerably depending on the regulatory framework of a particular state or region. The Trade Related Aspects of Intellectual Property Rights (TRIPS) agreement states that all World Trade Organisation (WTO) members should adopt a set of minimum standards on IPR, including pat- 
ents and copyrights. At the global level, the TRIPS agreement does not oblige WTO member countries to make legal provision for the patentability of genes and DNA sequences (OECD, 2014; Van den Belt, 2013).

3. The third threat relates to the non-transparent role of 'surrogate' companies that are formed by academic institutions. Jorge L. Contreras and Jacob S. Sherkow (2017: 698) are very critical of this model of "surrogate licensing" in which universities seek to outsource the licensing and commercialisation of a valuable patent portfolio to university spinoffs. ${ }^{3}$ They reviewed all of the CRISPR-Cas 9 surrogate licence agreements made publicly available in the USA. They found that in all principal surrogate licences the patent-holding institution has granted its surrogate companies the exclusive right to use CRISPR-Cas 9 to develop human therapeutics targeting any of the $20,000+$ genes that comprise the human genome. Because no single company would be able to develop, test and market therapeutics on the basis of even a fraction of the entire human genome, the surrogate companies are authorised and expected to sublicense their rights to others. Despite this, it is still rare for any surrogate company to explore the possibility of such cooperation. In addition, as noted by Contreras and Sherkow the occupation of universities with forming a model of 'surrogate licensing' tends to make them withdraw from their usual cooperation with the academic world, "what could rapidly bottleneck the use of CRISPR-Cas 9 technology to discover and develop useful human therapeutics" (Contreras and Sherkow, 2017: 698).

As stated in the introduction to this contribution, opposite trends can also be detected, e.g. academic institutions are reconceptualising licensing policy. The general notion that no single company will invest in developing or commercialising the patented technology unless that company is guaranteed an exclusive license is slowly changing. In the USA, National Institutes of Health recommended that patents on research tools developed using federal funding be licensed non-exclusively so as to promote their greatest utilisation, commercialisation and public availability. In the case of CRISPR-Cas 9, the earliest programmes of nonexclusive licensing are being entered into by universities. This is important because it is a broadly applicable 'platform' technology that could enable innumerable specific applications.

Both of the leading academic institutions involved in the mentioned patent fight over CRISPR-Cas 9 technology have also formed "profit 'surrogate' companies to manage university licensing" (Sherkow, 2017c: 565). The University of California has delegated all of its licensing rights concerning CRISPR-Cas 9 technology to Caribou Biosciences, a profit-based 'surrogate' company which in turn has granted an exclusive licence to Intellia Therapeutics to develop human therapies. Meanwhile, the MIT/Broad Institute is using the company Editas Medicine as its surrogate for human therapeutics (Egelie et al., 2016; Van Erp et al. 2015).

Some differences exist between the approaches of the University of California and the MIT/Board Institute. Editas Medicine licenses CRISPR patents on a non-exclusive basis beyond its use in human therapeutics (Mathias et al., 2018; Döring and Lim, 2017). It has already granted 60 non-exclusive licences. It also makes part of CRISPR knowledge freely available to the non-profit community. Editas Medicine's strategy is to pool patents with other companies directed at developing CRISPRCas 9. In this regard, in 2014 Editas Medicine developed the inclusive innovation model. In this innovation model, Editas Medicine has the right for a pre-defined period to decide whether it intends to pursue the gene of interest and to commit to funding and launching a programme. If Editas Medicine chooses not to pursue a new programme within this period, the intellectual property becomes available to a third party, thereby facilitating greater public benefit.

The University California is more circumspect about its licensing plan for CRISPR-Cas 9 technology. Intellia Therapeutics has announced the Global Agreement on the Foundational Intellectual Property for CRISPR-Cas9 Gene Editing Technology. Under this agreement, Intellia Therapeutics is committed to maintaining and coordinating the prosecution, defence and enforcement 
of the CRISPR-Cas9 foundational patent portfolio worldwide, and each of the co-owners of the intellectual property grants cross-consents to all existing and future licences and sublicences based on the rights of another co-owner. The main goal of such a patent pool is to protect the share of intellectual property rights among companies by approaching a global agreement (Samy, 2018; Mathias et al., 2018).

The strategy of non-exclusive licensing and cross-licensing pools used by Editas Medicine, Intellia Therapeutics and other 'surrogate' companies formed by the universities heralds a new policy in the IPR landscape of genetic engineering. However, even where such surrogate companies succeed in creating a set of such interlocking licence agreements, they cannot stop the risk of a slowdown in the advance of basic research because they are oriented to short-term profit rather than, say, the free flow of information and public access to knowledge. The last ones are ideals which should be lauded by academic scientists.

\section{Why the recent patent litigation over the CRISPR-Cas 9 genome- editing technology may be seen as a continuation of the long- running debates on biopatents}

The tendency to file the results of genetic engineering for patenting and other forms of IPR is not new. This issue has been the subject of critical and controversial discussions for more than 40 years. These controversial discussions have consistently had impacts extending beyond the economic domain. The question has arisen of why genes have ever been the subjects of patents. This question is changing into a (bio)ethical concern par excellence. The bioethical concerns of patenting inventions in genetic engineering have grown especially related to human genes and biomedicine. Van den Belt stated: "The legal and moral issues that synthetic biology and its medical applications are likely to raise with regard to intellectual property (IP) and patenting are increasing..... The problem becomes even worse if we have to zoom in on the medical applications of synthetic biology and the legal and moral issues they are going to raise with regard to intellectual property and patenting" (Van den Belt, 2013: 87). In that sense, we can also see the recent patent disputes over CRISPR-Cas 9 which are part of this wider issue of medical applications of synthetic biology as being a continuation of bioethical debates underway for 40 years.

If we look at history, the modification of living organisms with genetic engineering in the 1970s and 1980s opened up new possibilities for biotechnology to develop. This development soon led to appreciation of the commercial possibilities of genetic modification and the advantages of protecting developments by making claims in the patent system. This led to a situation where the emergence of new technology created new legal problems. Some kind of IPR revolution in genetic engineering first occurred in the USA. At the beginning of the 1980s, two parallel events facilitated this paradigm shift.

First, the attempt to assert ownership over biological components and entities became part of a much broader movement to transform living substances into marketable products. Early in the 1980s, the USA passed the well-known Bayh-Dole Act which assigned intellectual property rights over faculty discoveries from federally funded research to universities and emphasised the university's responsibility for commercialisation. The Bayh-Dole Act helped create whole new industries, such as biotechnology, where the USA holds a leadership role (Etzkowitz, 2002; Coriat and Orsi, 2002).

Second, the first patent application on any (man-made) living thing was imminent. After a lengthy series of lawsuits, the US Supreme Court awarded Chakrabarty a patent on Pseudomonas putida, a strain of bacterium he had transformed with several plasmids. It was the first patent application on a recombinant bacterium. The US Supreme Court held in 1980 that anything new under the sun that is made by man, whether living or non-living, can in principle be patented. This established a precedent for the patentability of living micro-organisms modified through human intervention. However, the Supreme Court did not set any boundaries on this new area of patentable material (Bhutkar, 2005). 
During the 1980s, the patentability of living organisms was further extended from bacteria to multi-cellular organisms. This process then continued with the patentability of the first animal. In 1984, Harvard University filed for a patent on laboratory mice, i.e. a genetically-altered mouse. The mouse had been modified to be particularly susceptible to cancer. In other words, it was a strain of mouse developed in the laboratory with a predisposition to develop tumours. The case is known as the 'Harvard Oncomouse' (Jasanoff, 2005: 210). The USPTO awarded the patent for the oncomouse in 1988, being the first time a patent had been granted to a transgenic non-human mammal whose germ cells and somatic cells contain a recombinant activated oncogene sequence. The argument for granting the patent for the 'Harvard Oncomouse' was that in this case the isolation and purification of a particular DNA sequence from the body turns it into something radically different from its natural state.

Along with the advance of genetic sequencing the pressure to submit everything to patent rights grew. Such processes already then triggered concerns over the ethical issues of biopatents (on top of the fear the pressure to submit the discoveries made in biogenetics to patents would slow research and clinical tests for genetic disease). There was increasing dissatisfaction with the patent regimes' approaches to living organisms.

In this period, two kinds of arguments emerged against the patenting of genes of living organisms:

1. The first argument was used more with regard to human genes. It is clear that increasing access to the human genome held profound implications for a re-thinking of human dignity. It was said that human genes are the common heritage of humanity and that patents could violate the idea of the human genome as the common heritage of humankind. Based on the common heritage principle, this argument mirrors the language of UNESCO's Universal Declaration on the Human Genome and Human Rights (UNESCO, 2003), which refers to the concept of human dignity. It assumes that the dignity of each human individually and of all human- ity would be affected if patents are sought for procedures or products claiming to alter the genetic identity of human beings. In that sense, the human genome is linked with human dignity and is by nature untouchable and non-patentable. Of course, underlying this basic argument against the patenting of human genes were deep concerns over a redefinition of life and their implications for human rights as well.

2. The second argument was based on the belief that the genes of all living beings (not only human beings) are naturally-occurring entities which are not invented but discovered. ${ }^{4}$ In this circumstances, the so-called "patentable subject matter doctrine" (Sherkow and Greely, 2015: 164) has been again used. At the core of this argument was the question of whether genetic substances that are subjected to human manipulations are 'natural' or 'artificial'. This issue attracted wider political and public attention because from the outset important differences in the patent regimes of the EU and the USA started to appear. Although in the EU there has also been discord over the issue of gene patents between the European Parliament, EPO and specialist law reform advisory bodies (Rimmer, 2008), under EU patent law such ethical objections have more often been recognised as a reason not to grant patent rights (see, e.g. Parthasarathy, 2015; Cook-Deegan and Heaney, 2010; Jasanoff, 2005). One reason was that the European Parliament, after 10 years of debate, had accepted the European Biotechnological Directive on the legal protection of biotechnological inventions (European Biotechnological Directive, 1998). This was later implemented in the regulations of the European Patent Convention (EPC), an intergovernmental treaty that established a common legal framework for patent regimes in EU member states, Norway and Switzerland. It is also true that, although the European Biotechnological Directive was an important element of European patent law that binds national governments, the ethical consideration of biopatents has in particular EU member states many times followed a dif- 
ferent course. Mostly they were free to judge for themselves whether to use a more or less strict bioethical approach in their patent regimes (Schneider, 2009; Gold and Gallochat, 2001; Mali, 2004). The same occurs today with the 'public order of morality' criteria. European patent law excludes from patentability any inventions whose commercial exploitation would be contrary to 'public order of morality' (OECD, 2014; Van den Belt, 2013).

The cases regarding the patenting of 'artificial life' are not explicitly addressed as something contrary to the 'public order of morality'. Put frankly, this requirement is difficult to satisfy not just in the USA, but in Europe as well. Let us take the example of synthetic biology, where physically 'isolating' the condition of the gene is not even necessary. It is entirely possible that one researcher could upload DNA sequences onto a computer, 'prints out' a copy of that DNA sequence and patents it as an invention or creates a novel DNA sequence with computer algorithms and inserts the sequence in an organism, and thus patents it.

In the USA, patent law has in some senses entirely avoided "the philosophical and ethical discussions" (Calvert, 2012: 172), even in the most controversial cases where the meaning of patent law was in most doubt. That was the practice at least until the well-known Myriad case in 2013. In the USA, unlike in the EU member states, the strengths of the patent courts have led to the weakness of the broader ethical reconsiderations of the function of biopatents. Courts are institutionally mandated to apply the law as they find it (Kleinman and Kinchy 2003). "Major legal disputes are disposed of as narrower questions of statutory interpretation, in accordance with technical criteria for granting patents, interpreted case-bycase by the courts" (Jasanoff 2005: 209).

It seems that the legal discourse in the USA called 'patent eligibility' (Sherkow and Greely, 2013: 1569), which ignores the ethical issues surrounding biopatents, was prevalent before the outcome of the Myriad case in 2013. ${ }^{5}$ The decision in the Myriad case brought an important change in American legal doctrine concerning patent law (Singh, 2015; Winickoff, 2015; Calvert, 2012). The Myriad case was the first to reject "the isolated and purified doctrine as a lawyer's trick" (Van den Belt, 2013: 92). In this case the US Supreme Court did not confirm a patent claim that supposedly covered isolated genomic DNA, i.e. DNA fragments of various sizes that have simply been removed from the surrounding genome. It was declared that separation of the gene from its surrounding genetic material is not an act of innovation, which was contrary to former patent court practices in the USA. Before the Myriad case, in the USA thousands of genes had already been patented.

Today, in the context of the legal interpretation of the ownership of CRISPR-Cas 9 technology an extremely important bioethical issue that arises is its ability to power gene drives which alter normal patterns of inheritance such that engineered genes are always passed on to future generations (Esvelt, 2016; Sherkow, 2017a). We have noted that from the very outset of developing recombinant DNA technology in the 1970s it was necessary to clarify whether and under which conditions and to what extent inventions related to living matter should be eligible for patent protection. In the setting of the 'patentable subject matter doctrine', the patenting of CRISPR-Cas 9 technology as such does not pose any specific bioethical issue. CRISPR-Cas 9 cannot itself be patented because it occurs as a natural biological process. Finally, Cas 9 is a naturally-occurring protein and part of a naturally-occurring bacterial process. But, unlike the BRCA genes in the Myriad case, CRIPSR-Cas 9 technology is subjected to patenting because scientists are able to alter, control and modify this technology to function in animal and human cells, a cellular system in which CRISPR-Cas 9 does not naturally function (Ku, 2017; Beale, 2015).

This means that bioethical issues emerge when patents related CRISPR-Cas 9 technology are used which offend the dignity and integrity of the human being. Today the realistic prospect exists that the CRISPR-Cas 9 technology could be used for germline gene therapy in humans to prevent genetically inherited diseases. Such germline interventions could make genetic alterations in gametes or embryos, which are carried by all of the cells of the resulting child and passed on to subsequent generations as part of the human gene pool. The use of CRISPR-Cas 9 technology in 
such 'gene drives' is extremely risky because they are forcibly heritable, making them difficult to control once put in place (Sharkow, 2017; Esvelt, 2016). In that sense, it is very important that CRISPR innovations intended to relate processes for modifying the germline genetic identity of human beings will not be rewarded by patents. In this situation, the deliberation about how, and by whom, the ownership of inventions using CRISPR-Cas 9 technology is to belong is extremely important.

Last but not least, CRISPR-Cas 9 technology has already been used for editing the genomes of animals. In the case of mosquitoes, CRISPRCas 9 was used to drive a cargo allele throughout the population that prevents the insect from acting as a vector for malaria. Alleles that prevent mosquitoes from acting as a vector naturally exist, meaning that a gene drive patent could not cover the allele itself. Yet, matters in patent practice are not as clear as seems at first sight. In the example of mosquitoes, it is possible to interpret the combination of CRISPR-Cas 9 with a natural allele intended to replace an existing one as either a composition of matter (nature) or as a new and useful improvement.

It will take some time for regulation to get up to speed with such a breakthrough technology like CRISPR-Cas 9 and thus, before then, it is important that all stakeholders involved consider the ethical issues

Today, one can see some differences in Europe and the USA in the evaluation of the new germ-line editing. The views held by American expert and policy actors on germ-line editing are much more pragmatic than those of their European counterparts. A report prepared by American academics states that human germ-line (heritable) genome editing should be allowed because, if regulated appropriately, the benefits for human health will outweigh the potential risks (National Academies of Sciences, Engineering, and Medicine, 2017).

Yet European academics who prepared a report on the risk of genome editing at practically the same time as their US colleagues had a much more precautionary view (EASAC Policy Report, 2017). While American experts support the idea of the science going forward before a general consensus based on deliberation that this approach is medically warranted, the academics from Europe suggest a worldwide moratorium on altering the genome to produce changes that could be passed on to future generations. It is clear these differences at the global level will probably also influence the prospects of future progress with the new CRISPR-Cas9 technology.

\section{Efforts for open access to knowledge in the whole field of synthetic biology and their impact on the search for an alternative ownership model in CRISPR-Cas 9}

CRISPR Cas 9 is an innovation which has revolutionised the entire field of synthetic biology. Synthetic biology (SB) may be seen as the part of genetic engineering with the most progress that is changing practically at an exponential pace. In the book What's Your Bio Strategy? (Cumbers and Schmieder, 2017), the opinions of dozens of leading academics and businessmen around the world are presented on what the further progress of SB will look like. Most interviewees assessed that SB, due to this new field, is slowly transforming into the next world-impacting technoscience.

In recent times we have often encountered the opinion that the transformation of biology into engineering science should fit well with the requirements of modern patent regimes. The biology began drawing on the engineering principles of standardisation, decoupling and abstraction with the aim to develop biological components that are interchangeable, functionally discrete and capable of being easily combined in modular fashion (see, e.g. Endy, 2005; Brent, 2004). Turning SB into some kind of engineering science would be proof that it is easier to submit inventions in SB to patenting (see, e.g. Oye and Wellhausen, 2010; Calvert, 2008). One example of the very aggressive use of IPR in synthetic biology is the efforts made by the John Craig Venter Institute to acquire extremely broad patent rights for new artificial life (Van den Belt, 2013). It is well known that Venter was at the centre of an attempt to patent genes already 30 years ago. One infamous example of such activity was a bid by the US National Institutes of Health, led by John Craig Venter, to patent thousands of short DNA 
sequences called Expressed Sequence Tags (or ESTs) in 1991-1992 (Calvert, 2012).

In my contribution, I showed that the most efficient mechanism for encouraging the ongoing progress of CRISPR-Cas 9, which entails the most revolutionary step in the progress of genetic engineering (and synthetic biology ${ }^{6}$ ), is to find an intermediate way that ensures a balance between providing sufficient openness for further basic research, while also giving sufficient intellectual property rights to incentivise innovators. In that sense, the case of a patent war between the University of California and the MIT/Broad Institute based on the 'winner-takes-all' principle (Feldman, 2016: 392) cannot be the ideal paradigm for the future.

Due to the expanding body of various or even contradictory views and policy practices that has built up over the last decade around the protection and openness of innovations in the new and emerging technologies, it is sometimes difficult to characterise the issue in any definitive way. Still, with the invention of CRISPR - Cas 9 we must become ever more aware that we need to find a balance between different mechanisms that will not only encourage short-term profit in science, but its wider public benefits (Levin and Leonelli, 2017). CRISPR technology is in many regards so different from classical approaches in genetic engineering that it is entirely justified to find new solutions in the field of IPR as well. The idea that the same IPR models can be applied to all fields of technology for all times no longer holds (Van den Belt, 2013; Rutz, 2009).

When innovations in such advanced niches of synthetic biology like CRISPR-Cas 9 are moving despite the patent system, not because of it, perhaps it is time in the last part of our discussion to briefly consider the advantages of three models which proclaim free access to knowledge. They have their roots in a movement called'access to knowledge' or "A2K" (Kapczynsky, 2010: 17). The A2K movement first came together in 2004 in response to the growing imbalance between privatised knowledge (that which is controlled by the intellectual property rights holder) and the knowledge commons (that which is 'owned' by the public). The A2K movement may be seen as a political reaction to the neoliberal agenda of intellectual property expansionism, but "it is also closely aligned with the rise of new emerging technologies that proved congenial to opensource approaches" (Krikorian, 2010: 57). The $\mathrm{A} 2 \mathrm{~K}$ movement raised fundamental questions about the production of ideas, goods and services created in the current knowledge-based economy, and about access to such ideas, goods and services. In order to avoid the further concentration of IPR and potentially adverse impacts on the progress of science, it suggested introducing complementary mechanisms for inducing innovation activity. Consistent with these basic principles of the $\mathrm{A} 2 \mathrm{~K}$ movement, various models of free access to information have been proposed for supporting the sharing of information in genetic engineering while maintaining incentives for innovation.

As noted by Jane Calvert (2012), since the idea of 'openness" is vague and interpreted in many different ways in the context of theory, one can identify at least three different general models of scientific and technological knowledge that offer the opportunity for the free flow of information: the open innovation model, the open science model, and the open source model. Since they were enacted in various settings and times, they usually require assessments on a case-by-case basis. Let us briefly look at them.

1. Open innovation model: the term 'open innovation' is used very broadly. It generally refers to major global changes in the behaviour of the business-enterprise sector. Created by Chesbrough to reduce the gap between industry and academia, the open innovation model is known as "the use of purposive inflows and outflows of knowledge to accelerate internal innovation, and expand the markets for external use of innovation, respectively" (Chesbrough, 2006: 9). In such models, progress in innovativeness occurs on the basis of internal and external sources of knowledge and therefore in collaboration with several R\&D actors (Bogers et al., 2018; West et al., 2014). It leads to stronger collaboration between companies with the aim of intensifying innovation and bringing in new resources not available internally. In the con- 
text of open innovation, intellectual property plays a new role which no longer reflects the usual defensive mechanism adopted by companies (Enkel et al., 2009). More precisely, up until a few years ago most middle-cap companies made use of their patents to block competitors and to freely operate in the market. As several authors note, to deal with the possible constraints on knowledge transfer in open collaborative innovation there is primarily a need to develop adequate licensing strategies (Bogers et al., 2012; Grandstrand, 2011). In the open collaborative innovation model framework, cross-licences which represent less restrictive licensing strategies are especially important. In a cross-licensing agreement, the partners allow each other to use the knowledge they need for the collaboration. Alternatively, a less explicit 'umbrella agreement' is used which states that knowledge should and will be shared to the extent needed and the partners will only use this in relation to the collaboration and not internalise it privately. Although CRISPR technology holds tremendous innovation potential in agriculture, cross-licensing strategies are not regarded as the best way if they lead to the creation of a narrow oligopoly of a few interconnected multinationals. Such megamerger waves (for example the Monsanto/ Bayer merger transaction) could limit the disruptive potential of this technology.

Considering recent developments in human genome-editing technology, some authors suggest following earlier models developed by the licensing programmes of some universities. Such a positive case may be the licensing programme at Stanford University which created a pioneering licensing programme that provided a predictable legal framework for the use of its inventions. Non-exclusive licences were available to both companies and academic institutions, but on different terms (Egelie et al., 2016).

2. Open science model: This model is essentially non-pecuniary in the exchange of ideas although it clearly requires money for the production of ideas. It was described by Dasgupta and David already in 1994 (Das- gupta and David, 1994). Historically, in the early stages of several industries a similar model involving the free exchange of ideas and improvements was operative. Attention in the open science model is not given to IPR issues, but a great deal of effort is devoted to interoperability. For instance, ever more firms in knowledge-intensive sectors are participating in open science because it facilitates the disclosure of scientific discoveries through publications in academic journals (Jong and Slavova, 2014). Industry scientists even appear to have their internal career paths tied to publishing success and career ladders that resemble those in the academic science sector. This type of disclosure strategy encountered by certain firms is sometimes called the strategy of "patent-paper pairs" (Gans et al., 2017: 824). Many other initiatives connected with the open science model have emerged. One of the largest patent holders in the world (IBM) substantially altered its corporate policy on the management of patents already in 2006, especially in the areas of software and business method patents. Among other initiatives, the Open Collaborative Research (OCR) programme was established to support open-source software research between IBM and universities (Hall, 2010). Many recent initiatives refer to open data platforms. The EGI Open Data Platform, built on OneData technology, was developed to provide openly accessible data (Viljoen et al., 2016).

3. Open source model: It contains elements of both the private investment model (in which knowledge is appropriated privately) and the collective action model (with the emphasis on public knowledge). In that sense, it is some kind of "private-collective innovation model" (Von Hippel and Von Krogh, 2003: 210). Social actors in this model produce public goods, but also capture private benefits that exceed their participation costs (Gans et al., 2017). The open source model is interested in enabling certain legally binding forms of access. In fact, the term "open source" refers to information that can be modified because its design is publicly accessible. A good example is the Registry of Standard Biological Parts estab- 
lished by the International Genetically Engineered Machine (iGEM) Foundation (iGEM, 2017). This type of communal approach to property is seen as promoting "freedom to create" and the advancement of synthetic biology as one of the most revolutionary fields today (Hilgartner, 2012). The Registry runs and grows according to the "Get \& Give or Share" philosophy. Users get in parts, samples, data and tools to work on their synthetic biology projects. They give back to this biobase the new parts they have made, as well as data and experience on new and existing parts. Finally, users share their experience and collaborate in the Registry's open community through their wikis, forums and other social tools. $^{7}$

The BioBricks Foundation is an interesting proponent of an open-source synthetic biology community because its standardised transfer agreements contain ethical constraints (BioBricks Foundation, 2017). Enthusiasts from various academic institutions and industry who set up the Registry of Standard Biological Parts or BioBricks have articulated their open-source aspirations because they are explicitly attempting to follow the solutions seen in the computer sciences. They are inspired by the open-source movement in the development of computer software (Singh, 2015). In the case of computer software, copyright law was used based on the General Public Licence ('copyleft'). The General Public Licence ('copyleft') ensures that newly written software code is not privately appropriated but remains free for all to use. The main argument for using the BioBricks Registry was that the modular 'entities' produced by SB are ideal for open source because they can be worked on simultaneously by a large community of both users and producers, and this can speed up development of the field. A good example of such an 'entity' is the various types of bacterias producing biofuel. If the many parts of such bacterias were to be protected by different patents (which would probably be held by several rights holders), we would very quickly find ourselves faced with a 'patent thicket'. A patent thicket is a set of closely related and possibly overlapping patent rights to a certain technol- ogy, thereby requiring anyone wishing to use, build on or commercialise that technology to obtain licences from a number of patent holders (Shapiro, 2001). In some technologies, a 'patent thicket' is leading to an absurd situation. Joshua M. Pearce reported that "any innovator wishing to work on or sell products based on single-walled carbon nanotubes in the United States must wade through more than 1,600 US patents and then obtain multiple licenses to use any much of the basic and foundational information covered in those patents" (Pearce, 2012: 519).

The models of open science presented above allow the conclusion that the situation in reality is probably more complex than might be seen in theory. Namely, cases in practice oscillate between openness and closeness. The biggest challenge is therefore to strike the balance between providing sufficient openness for further scientific investigation and adequate policy instruments to provide incentives for innovation and commercial development. Last but not least, the whole field of genetic engineering has only recently considered open-source approaches. Here, efforts to establish an open-source community are still in their initial stages. Yet, within this open-source community there exist a vast array of possibilities. Or, to use the metaphors introduced by Drew Endy and further developed by Jane Calvert (2012), a diverse open-source-proprietary ecology is forming.

In our view, the open source model practised in the context of BioBricks could be of interest for CRISPR-Cas 9 technology. It could encourage the stakeholders involved from the academic and business-enterprise sectors to intend to provide more attention to free access to CRISPR-Cas 9 technology. In the BioBrick User Agreement (BUA), the inventors are required to publicly share their knowledge, leading to a productive relationship between private initiative and the public interest. Such a combination of the two interests holds significant implications for the further progress of CRISPR-Cas 9 technology, unlike the recent IRP situation regarding this revolutionary technology which is opaque due to the hubbub created by the never-ending patent battles. The BioBricks model is also of interest for another reason. Its standardised transfer agreements contain ethical constraints. The BioBrick User Agreement 
contains ethical clauses which prohibit intentionally harmful uses of synthetic biology. Of course, critics who question the quality of BioBricks can also be found (Hilgartner, 2015). They criticise its design of a regime of openness as well as its partsbased approach to synthetic biology. Still, there is no doubt that the BioBrick model could be seen as a vanguard vision towards new solutions in the social regulation of new and emerging technologies at large whose benefits will be seen at some stage in the future.

\section{Conclusion}

This contribution had two aims. First, it tried to critically examine the risks emerging from the increased efforts of the business-enterprise and academic sectors to monopolise their inventions related to human genome editing technology with the help of strict forms of IPR. Second, another goal of the article was to point out that the stronger processes of privatisation and the use of strict forms of IPR also carry (bio)ethical implications. Of course, bioethical dilemmas did not begin with the emergence of the new human genome editing technologies. They have accompanied practically the entire history of biogenetics. In that sense, we see the recent patent disputes over CRISPR-Cas 9 as a continuation of the already long-running bioethical debates in biogenetics generally. Despite this, they have obtained new dimensions in recent times. As we aimed to highlight, the ethical risk to the dignity of human beings arises from the new CRISPR technology's ability to modify the germline genetic identity of human beings.

Concerning the strict enforcement of patent protection by the inventors of new human genome editing technologies, especially those coming from the academic sector, we saw that these processes could cause a 'bottleneck' hindering any faster progress of the whole field of biotechnology. What we especially attempted to emphasise is the threat of the brutal commercial and profit logic continuing to underpin the ownership models, including wide-scale litigation over patents, will destroy the concept of the free exchange of information in basic academic science. Namely, it seems that just in the case of the CRISPR technology, which is turning the ivory tower of biogenetics into a multibilliondollar technological enterprise, the patenting regimes have started to too strongly dictate the behaviour of academic science. CRISPR research is a large field that attracts contributions from many talented scientists around the world. The US Patent and Trademark Office has issued more than 80 patents with claims to CRISPR and/or Cas9 to more than 300 inventors from nearly 60 applicant organisations. The European Patent Office has issued more than 20 such patents to approximately 30 inventors from about 10 applicant institutions. In addition, around the world more than 1,500 applications have been filed (but not yet granted).

The central thesis of my contribution is that the biggest challenge facing the academic research sector is to find an intermediate way that ensures a balance between providing sufficient openness for furthering the research into CRISPR as 'niche' areas of genetic engineering, while also ensuring sufficient intellectual property rights that give incentives for innovators. Namely, the solution to this issue will hold many positive consequences for the future progress of human genome editing technologies and may, in turn, generate proper responses to the increasing bioethical concerns. Patents are supposed to be a game of winnertakes-all in which the one who arrives first wins. In the article, I showed the clearest indicator of the increased tendency of academic institutions to commercially privatise their knowledge is patent litigation. Such uncompromising battles over patent rights bring many negative implications, some of which were presented in the article.

In view of the assessed negative implications, the patent system's structure stands in contrast to that of other intellectual property regimes in which society recognises the rights of multiple parties to the chase. Establishing alternative ways to a strict IPR regime is particularly important given the twofold tendency of the recent progress of human genome editing technology, i.e. its globalising tendency and its tendency to radically transform human beings and social life. Both tendencies are very realistic and very promising.

In the last part of our article, I presented various efforts made to ensure open access to scientific 
knowledge. The three different general models of scientific and technological knowledge that offer an opportunity for freer flow of information are addressed, i.e. the open innovation model, the open science model, and the open source model. Models encapsulating a free approach to scientific knowledge especially in the domain of synthetic biology are underway. Notwithstanding this, as noted in the article, while these projects are only in their initial stages they have good prospects because they represent alternative ways to a strict IPR regime. Following the classification of some authors who distinguish different models of open science, I noted, also with reference to certain cases, that to ensure the further progress of CRISPR technology the open source model as practised in the BioBricks context might be interesting. It encourages the stakeholders involved from the academic and business-enterprise sectors to intend to provide more attention to free access to newly created knowledge in the domain of synthetic biology. Namely, lying in the centre of the BioBricks programme is a "Get \& Give or Share" philosophy that entails reciprocal obligations to give something in exchange for a gift. In practice, while this is not always easy to manage, it could become a good case for the more balanced social regulation of all newly emerging technologies. 


\section{Literature}

Akst J (2017) UC Berkeley Receives CRISPR Patent in Europe. The Scientist Magazine, 24 March. Available at: https://www.thescientist.com/?articles.view/articleNo/48987/title/UC-Berkeley-Receives-CRISPR-Patentin-Europe/ (accessed 21. 12.2018).

Barrangou R and Doudna J (2016) Applications of CRISPR technologies in research and beyond. Nature Biotechnology 34(9): 933-941.

Beale K (2015) The CRISPR Patent Battle: Who Will be "Cut" Out of Patent Rights to One of the Greatest Scientific Discoveries of Our Generation? Boston College Intellectual Property \& Technology Forum, February 9. Available at: http://bciptf.org/wp-content/uploads/2016/02/KBeale-CRISPR.pdf (accessed 30.8. 2019).

Bhutkar A (2005) Synthetic Biology. Navigating the Challenges Ahead. The Journal of Biolaw \& Business 8(2): 1-11.

BioBricks Foundation (2017) Registry of Standard Biological Parts. Available at: http://parts.igem.org/Main_ Page (accessed 27.1. 2018).

Bogers M, Bekkers R and Granstrand O (2012) Intellectual Property and Licensing Strategies in Open Collaborative Innovation. In: Pablos C, Heredero D and López D (eds) Open Innovation at Firms and Public Administrations: Technologies for Value Creation. Hershey: IGI Global, pp.37-58.

Bogers M, Fossb N and Lyngsiec J (2018) The "human side" of open innovation: The role of employee diversity in firm-level openness. Research Policy 47(1): 218-231.

Brent R (2004) A partnership between biology and engineering. Nature Biotechnology 22(10), 1211-1214.

Calvert J (2008) The commodification of emergence: systems biology, synthetic biology and intellectual property. Biosocieties 3(4): 383-398.

Calvert J (2012) Ownership and sharing in synthetic biology: A 'diverse ecology' of the open and the proprietary? BioSocieties 7(2): 169-187.

Carson P and Mulvaney M (2018) CRISPR patents: guidance from US courts. Life Science Intellectual Property Review, 19. September. Available at: https://www.kirkland.com/-/media/publications/article/2018/09/lifescience-intellectual-property-law-review-cris.pdf (accessed 13.1. 2019).

Chesbrough H (2006) Open Innovation: A New Paradigm for Understanding Industrial Innovations. In: Chesbrough H, Vanhaverbecke W and West J (eds) Open Innovation: Researching a New Paradigm. Oxford: Oxford University Press, pp.1-15.

Contreras J and Sherkow J (2017) CRISPR, surrogate licensing, and scientific discovery. Science 355 (6326): 698-700.

Cook-Deegan R and Heaney C (2010) Patents in genomics and human genetics. Annual Review of Genomics and Human Genetics 11 (22. September): 383-425.

Coriat B and Orsi F (2002) Establishing a new intellectual property rights regime in the United States: Origins, content and problems. Research Policy 31(2): 241-267.

Cumbers J and Schmieder K (2017) What's Your Bio Strategy? China, Indonesia, U.K., USA: Pulp Bio Books Com.

Dasgupta P and David PA (1994) Toward a new economics of science. Research Policy 23(5): 487-521.

Döring M and Lim D (2017) Questions about CRISPR. Intellectual Property Magazine, 29 April. Available at: http://www.allenovery.com/SiteCollectionDocuments/Questions\%20about\%20CRISPR.pdf (accessed 19. 12.2018).

EASAC Policy Report (2017) Genome editing: scientific opportunities, public interests and policy options in the European Union. German National Academy of Sciences, March 2017. 
Egelie K, Graff G and Strand S (2016) The emerging patent landscape of CRISPRCas gene editing technology. Nature Biotechnology 34(10): 1025-1031.

Endy D (2005) Foundations for engineering biology. Nature 438(7067): 449-453.

Enkel E, Gassmann O and Chesbrough H (2009) Open R\&D and open innovation: exploring the phenomenon. R\&D Management 39(4): 311-314.

Esvelt K (2016) Strategies for Responsible Gene Editing. Project Syndicate, 25 January. Available at: https:// www.project-syndicate.org/commentary/crispr-gene-drive-editing-rules-by-kevin-m-esvelt-2016-01 [https://perma.cc/ZP3A-89CX] (accessed 31.1. 2019).

Etzkowitz H (2002) MIT and the Rise of Entrepreneurial Science. London and New York: Routledge.

European Biotechnological Directive (1998) Directive 98/44/EC of the European Parliament and of the Council of 6 July 1998 on the Legal Protection of Biotechnological Inventions. Available at: http://europa. eu.int/eurlex/pri//en/oj/dat/1998/1_213199807en00130021.pdf (accessed 8.1.2018).

Feldman R (2016) The CRISPR Revolution: What Editing Human DNA Reveals About the Patent System's DNA. UCLA Law Review Discourse 64(May 30): 392-412.

Feldman M, Colaianni A and Kang C (2007) Lessons from the Commercialization of the Cohen-Boyer Patents: The Stanford University Licensing Program. In: Krattiger A et al. (eds) Intellectual Property Management in Health and Agricultural Innovation: A Handbook of Best Practices, Vol. 1 and 2. Oxford, Davis, Rio de Janeiro: Oswaldo Cruz Foundation and BioDevelopments-International Institute, pp. 1797-1807.

Gans, J, Murray F and Scott S (2017) Contracting over the disclosure of scientific knowledge: Intellectual property and academic publication. Research Policy 46(4): 820-835.

Gold R and Gallochat A (2001) The European Biotech Directive: past as prologue. European Law Journal 7(3): 331-366.

Graff G and Johansen B (2016) The emerging patent landscape of CRISPR-Cas gene editing technology. Nature Biotechnology 34 (10) 1025-1031.

Granstrand O (2011) Industrial Innovation Economics and Intellectual Property (6th ed.). Gothenburg: Svenska Kulturkompaniet.

Grens K (2016) That Other CRISPR Patent Dispute. The Broad Institute and Rockefeller University disagree over which scientists should be named as inventors on certain patents involving the gene-editing technology. The Scientists, 31 August. Available at: https://www.thescientist.com/?articles.view/articleNo/46921/title/ That-Other-CRISPR-Patent-Dispute/ (accessed 8.1.2018).

iGEM (2017) Registry of Standard Biological Parts. Available at: http://parts.igem.org/Main_Page (accessed: 22.1.2018).

Halilem N, Amaraa N, Olmos-Peñuelab J and Mohiuddin M (2017) To Own, or not to Own: A multilevel analysis of intellectual property right policies' on academic entrepreneurship. Research Policy 46(8): 14791489.

Hall B (2010) Open Innovation and Intellectual Property Rights. The Two-edged Sword. Japan Spotlight 1: 18-19. Available at: https://pdfs.semanticscholar.org/5126/5c3a9c1d699a69240e602a0b869d5273e991. pdf (accessed: 24.1.2018).

Heller M and Eisenberg R (1998) Can patents deter innovation? The anticommons in biomedical research. Science 280(5364): 698-701.

Hilgartner S (2012) Novel Constitution? New Regimes of Openness in Synthetic Biology. BioSocieties 7(2): 188-207.

Hilgartner S (2015) Capturing the imaginary. Vanguards, visions and the synthetic biology revolution. In: Hilgartner S, Miller CA and Hagendijk R (eds) Science and Democracy. Making knowledge and making power in the biosciences and beyond. New York and London: Routledge, pp. 33-56. 
Jasanoff S (2005) Designs on Nature. Science and Democracy in Europe and in United States. Princeton: Princeton University.

Jasanoff S, Hurlbut BJ and Saha K (2015) CRISPR Democracy: Gene Editing and the Need for Inclusive Deliberation. Issues in Science and Technology 32(1): 25-32.

Jong $S$ and Slavova K (2014) When publications lead to products: The open science conundrum in new product development. Research Policy 43(4): 645-654.

Kapczynski A (2010) Access to Knowledge: A Conceptual Genaology. In: Krikorian G and Kapczynski A (eds) Access to Knowledge: In the Age of Intellectual Property. New York: Zone Books, pp.17-57.

Kleinman D and Kinchy A (2003) Why ban bovine growth hormone? Science, social welfare, and the divergent biotech policy landscapes in Europe and the United States. Science as Culture 12(3): 375-414.

Klueter T, Monteirob F and Dunlapc D (2017) Standard vs. partnership-embedded licensing: Attention and the relationship between licensing and product innovations. Research Policy 46(9): 1629-1643.

König H, Frank D, Heil R and Coenen C (2013) Synthetic Genomics and Synthetic Biology Applications Between Hopes and Concerns. Current Genomics 14(1): 11-24.

Krikorian G (2010) Access to Knowledge as a Field of Activism. In: Krikorian G and Kapczynski A (eds) Access to Knowledge. In the Age of Intellectual Property. New York: Zone Books, pp.57-99.

Ku D (2017) The Patentability of the Crispr-Cas9 Genome Editing Tool. Chicago-Kent Journal of Intellectual Property 16(2): 408-439.

Lander E (2016) The Heroes of CRISPR. Cell 164(1): 18-28.

Levin N and Leonelli S (2017) How Does One "Open" Science? Questions of Value in Biological Research. Science, Technology \& Human Values 42(2): 280-305.

Mali F (2004) Recent dilemmas in the social and legal regulation of biotechnology in the European Union. Vest - Journal of Science Technology Studies 17(3-4): 39-60.

Mali F (2014) How to address the policy and ethical issues emerging with new technology: the case of synthetic biology in a small country. NanoEthics 12(1): 61-73.

Mathias T, Ropka S and Clegg R (2018) The CRISPR Tug of War. IPWatchdog, 17 August. Available at: https:// www.ipwatchdog.com/2018/08/17/crispr-tug-of-war/id=100378/ (accessed: 1.2. 2019).

Merton R (1973) The Sociology of Science. Chicago: University of Chicago Press.

Merz J and Henry M (2004) The prevalence of patent interferences in gene technology. Nature Biotechnology 22(2): 153-154.

National Academies of Sciences, Engineering, and Medicine (2016) Gene Drives on the Horizon: Advancing Science, Navigating Uncertainty, and Aligning Research with Public Values. Washington, DC: The National Academies Press.

National Academies of Sciences, Engineering, and Medicine (2017) Human Genome Editing: Science, Ethics, and Governance. Washington, DC: The National Academies Press.

Nicol D and Nielsen J (2003) Patents and medical biotechnology. Occasional Paper No. 6. Centre for Law and Genetics. Centre for Law and Genetics at University of Tasmania. Available at: https://eprints.utas.edu. au/2550/1/NandN_final.pdf (accessed: 21.8. 2019).

Nuffield Council for Bioethics (2002) The Ethics of Patenting DNA: A Discussion Paper. London: Nuffield Council of Bioethics.

Nuffield Council for Bioethics (2016) Genome editing and ethical review. London: Nuffield Council on Bioethics. 
OECD (2014) Emerging Policy Issues in Synthetic Biology. OECD Publishing. Available at: http://www.oecdilibrary.org/science-and-technology/emerging-policy-issues-in-synthetic-biology_9789264208421-en. (accessed 5.10.2017).

Oye K and Wellhausen R (2010) The Intellectual Commons and Property in Synthetic Biology. In: Schmidt M, Ganguli-Mitra A and Huib V (eds) Synthetic Biology: The technoscience and its societal consequences. Heidelberg: Springer, pp.121-140.

Parthasarathy S (2015) Co-producing knowledge and political legitimacy: Comparing life form patent controversies in Europe and the United States. In: Hilgartner S, Miller CA, Hagendijk R (eds) Science and Democracy: Making knowledge and making power in the bioscience and beyond. New York and London: Routledge, pp.74-93.

Pearce J (2012) Physics: Make nanotechnology research open-source. Nature 491(22 November): 519-521.

Rimmer M (2008) Intellectual Property and Biotechnology. Biological Inventions. Cheltenham: Edward Elgar Publishing Limited.

Rutz B (2009) Synthetic biology and patents. A European perspective. EMBO Reports 10 (Special Issue): 14-17.

Sampat B and Shadlen K (2017) Secondary pharmaceutical patenting: A global perspective. Research Policy 46(3): 693-707.

Samy M (2018) CRISPR genome-editing market opportunity and key players. Research White Paper. New York: ARK Invest. Available at: https://research.ark-invest.com/hubfs/1_Download_Files_ARK-Invest/White_ Papers/ARK\%20Invest_081318_White\%20Paper_CRISPR\%200pportunity.pdf?hsCtaTracking=3e9ae410326d-4658-9a4a-fd6c4cb7b263\%7Cfa54a728-0144-4138-a518-b0051eae3b7f (accessed 4. 3. 2019).

Schneider I (2009) Governing the patent system in Europe: the EPO's supranational autonomy and its need for a regulatory perspective. Science and Public Policy 36(8): 619-629.

Shapiro C (2001) Navigating the patent thicket: Cross licenses, patent pools, and standard setting. In: Jaffe AB, Lerner J and Stern S (eds) Innovation Policy and the Economy. Cambridge, MA: MIT Press. pp. 119-150.

Sherkow J (2016) Who Owns Gene Editing? Patents in the Time of CRISPR. Biochemist 38, (April 5): 26-30.

Sherkow J (2017a) Patent protection for CRISPR: An ELSI review. Journal of Law and the Biosciences 4(3): 565-576.

Sherkow J (2017b) Inventive Steps: The CRISPR Patent Dispute and Scientific Progress. EMBO Reports 18(7): 1047-1050.

Sherkow J (2017c) How Much Is a CRISPR Patent License Worth? Pharma \& Healthcare, 21 February. Available at: https://www.forbes.com/sites/jacobsherkow/2017/02/21/how-much-is-a-crispr-patent-licenseworth/\#6c6541ab6b77 (accessed 16.11.2017).

Sherkov J and Greely H (2013) The Future Gene Patents and the Implications for the Medicine. AMA Internal Medicine 173(17): 1569-1570.

Sherkow J and Greely H (2015) The History of Patenting Genetic Material. Annual Review of Genetics 49(1): 161-182.

Singh T (2015) Open Source business models and synthetic biology. Chicago - Kent Journal of Intellectual Property 14(2): 455-484.

Specter M (2015) The Gene Hackers. A powerful new technology enables us to manipulate our DNA more easily than ever before. The New Yorker, 9 November. Available at: http://www.newyorker.com/ magazine/2015/11/16/the-gene-hackers (accessed 12.11.2017).

Summerfield M (2015) CRISPR - Will This Be the Last Great US Patent Interference? Patentology, 11 July. Available at: https://blog.patentology.com.au/2015/07/crispr-will-this-be-last-great-us.html. (accessed 1. 3. 2019). 
United States Court of Appeals for The Federal Circuit (2018) Appeal from the United States Patent and Trademark Office, Patent Trial and Appeal Board in No. 106,048. 10 September. Available at: http://www.cafc. uscourts.gov/sites/default/files/opinions-orders/17-1907.Opinion.9-10-2018.pdf. (accessed 12.3.2019).

UNESCO (2003) Universal Declaration on the Human Genome and Human Rights. In: Sandor J (ed) Society and Genetic Information: Codes and Laws in the Genetic Era. Budapest: Central European University Press. pp. 283-290.

Van den Belt H (2013) Synthetic biology, patenting, health and global justice. Systems and Synthetic Biology 7(3): 87-98.

Van Erp P, Bloomer G, Wilkinson R and Wiedenheft B (2015) The History and Market Impact of CRISPR RNAguided nucleases. Current Opinion in Virology 12 (June): 85-90.

Van Zimmeren E, Vanneste S and Matthijs G (2011) Patent pools and clearinghouses in the life sciences. Trends in Biotechnology 29(11): 569-576.

Viljoen M, Lukasz D and Bartosz K (2016) Towards European Open Science Commons: The EGI Open Data Platform and The EGI DataHub. Procedia Computer Science 97: 148-152.

Von Hippel E and Von Krogh E (2003) Open source software and the 'private-collective' innovation model: Issues for organization science. Organization Science 14(2): 209-223.

West J, Salter A and Vanhaverbeke W (2014) Open innovation: The next decade. Research Policy 43(5): 805-811.

Winickoff D (2015) Biology denatured: The public-private lives of lively things. In: Hilgartner S, Miller CA and Hagnedijk R (eds) Science and Democracy: Making knowledge and making power in the biosciences and beyond. New York and Abingdon: Routladge, pp. 33-56. 


\section{Notes}

1 If patents or patent applications overlap and the first person to invent is in dispute, then the patent office initiates what is called an interference proceeding, with intricate rules about deciding on the priority of invention. Interferences are more than twice as common in biotechnology patents than in any other patent class, and six times more frequent than patents on average (Merz and Henry, 2004).

2 The CRISPR system is the adaptive and inheritable immune system of certain bacteria and archaea, which are prokaryotes. Prokaryotes are simple single-celled organisms that lack a nucleus. Unlike prokaryotes, eukaryotic cells have many features such as a membrane-bound nucleus, which stores the cell's genetic information organelles, which are not found in prokaryotic cells. Animals and plants are eukaryotes.

3 Researchers recently suggest that licensing is no longer a uniform type of external knowledge-sourcing strategy. Namely, if a simpler or 'standardised' form of licensing gives the licensee the exclusive right to use the knowledge in exchange for money but without mutual interactions and resource sharing between licensee and licensor, then 'partnership-embedded licensing' embeds licensing in a broader partnership or an alliance that includes the mutual sharing of resources and joint R\&D efforts (Klueter et al., 2017). The standardised form of licensing is dominant when it comes to cooperation between the academic sector and business-enterprise sector.

4 In our common use of the term, a 'discovery' is the acquisition of knowledge of a new but already existing fact about the world. An 'invention', on the other hand, is something that someone creates or develops which did not previously exist. "Thus, on the usual interpretation of the words, it seems apparent that the identification of a gene is a discovery, since genes exist in the world, in our bodies" (Nuffield Council for Bioethics, 2002: 23).

5 The case regards patent claims covering BRCA1 and BRCA2. The patent claim was made by the Myriad Genetics company. Both genes are critical to assessing early-onset breast and ovarian cancer risk.

6 According to some experts, synthetic biology is interpreted as a linear continuation of former developmental stages in genetic engineering. Other experts say that synthetic biology represents a "game changer" in progress of genetic engineering (Mali, 2014).

7 Despite its open-source credo, iGEM leaves open the possibility of filing patents on applications and combinations of their standardised biological parts. This means options exist to facilitate or expand intellectual property requirements in the iGEM research frame. As noted by D. Endy (2005), iGEM may therefore provide an ideal testing ground for experimentation on open and intellectual property schemes. 